MIMBAR

JURNAL PENELITIAN SOSIAL DAN POLITIK

\title{
FUNGSI KEPEMIMPINAN DALAM MENINGKATKAN PRESTASI KERJA PEGAWAI KANTOR CAMAT KEDURANG KABUPATEN BENGKULU SELATAN
}

\author{
Oleh: \\ Soehito Efendi*, Edi Darmawi, Hernowo Noviyanto \\ *Email : soehito@unihaz.ac.id \\ Program Studi Administrasi Publik Fakultas Ilmu Sosial dan Ilmu Politik \\ Universitas Prof. Dr. Hazairin, SH Bengkulu
}

\begin{abstract}
ABSTRAK
Penelitian ini bertujuan untuk mengetahui fungsi kepemimpinan dalam meningkatkan prestasi kerja pegawai Kantor Camat Kedurang Kabupaten Bengkulu Selatan. Karena diharapkan fungsi kepemimpinan dari camat ini nanti dapat meningkatkan prestasi kerja pegawai, sebab dalam observasi sebelumnya terindikasi bahwa prestasi kerja pegawai kecamatan masih belum maksimal. Penelitian ini termasuk dalam penelitian kualitatif deskriptif dengan mengacu pada indikator Fungsi kepemimpinan pegawai Hadari Nawawi (1992). Penelitian ini dilakukan di Kecamatan Kedurang, narasumber dari Camat Kecamatan Kedurang, Sekretaris Camat Kedurang, Kasi Pelayanan Umum Kecamatan Kedurang, Kepala Desa Keban Agung II dan Tokoh Masyarakat. Teknik pengumpulan data dilakukan dengan observasi, wawancara, dokumen dan catatan lapangan. Kemudian data dianalisis secara deskriptif kualitatif. Hasil penelitian menunjukkan bahwa prestasi kerja pegawai secara keseluruhan sudah dapat dikatakan optimal, walaupun masih ada indikator yang tidak maksimal, SOP menjadi pedoman kerja bagi pegawai, prestasi kerja pada pelayanan umum masih dikategorikan belum maksimal, namun pada fungsi partisipatif sudah maksimal terlihat dari keikutsertaan pegawai dalam kegiatan dan rencana kerja pemerintah kecamatan yang selalu diikuti dengan aktif dan konsultatif. SDM sebagian pegawai yang masih rendah sehingga tidak dapat mencerna dengan baik instruksi dari camat, seperti masih ada pegawai yang kurang termotivasi dan tidak dapat mengoperasikan komputer, dengan adanya pegawai diharapkan pekerjaan kantor dapat terselesaikan dengan tepat waktu, dan outputnya adalah pelayanan yang prima dan pemberdayaan bagi masyarakat kecamatan kedurang.
\end{abstract}

Kata Kunci : Fungsi Kepemimpinan, Prestasi Kerja, Kecamatan Kedurang 
MIMBAR

JURNAL PENELITIAN SOSIAL DAN POLITIK

Juni 2019 ISSN : 2252-5270 \& E-ISSN : 2620-6056 Volume 8 No. 1

\section{A. Pendahuluan}

Berlakunya Undang Undang Nomor 6 Tahun 2014 tentang desa, semoga dapat membawa perubahan yang mendasar dalam sistem dan struktur pemerintahan desa serta membawa dampak yang sangat luas bagi penyelenggaraan pemerintahan, perencanaan pembangunan, pengelolaan keuangan, dan sistem penganggaran dalam menunjang penyelenggaraan pemerintahan di desa.

Kepemimpinan dapat diartikan sebagai pelaksanaan otoritas dan pembuatan keputusan. Ada juga yang mengartikan bahwa kepemimpinan merupakan suatu inisiatif untuk bertindak yang menghasilkan suatu pola yang konsisten dalam rangka mencari jalan pemecahan dari suatu persoalan bersama. Menurut George R. Terry (1960:493), bahwa kepemimpinan adalah aktivitas untuk mempengaruhi orangorang supaya diarahkan dalam mencapai tujuan organisasi. Pemahaman tentang esensi kepemimpinan semakin diperkaya oleh pengalaman orang-orang yang dalam perjalanan hidupnya diberi atau memperoleh kesempatan untuk menduduki jabatanjabatan pimpinan, baik pada tingkat rendah, menengah, maupun tingkat puncak.

Maksudnya adalah penggabungan antara pemahaman teoritikal dan empiris telah memberikan keyakinan yang semakin mendalam pada organisasi, tentang pentingnya fungsi kepemimpinan dalam usaha organisasi untuk mencapai tujuan dan berbagai sasarannya. Pemimpin harus menyadari bahwa dunia saat mi dihadapkan pada lingkup yang tanpa batas, dan keberagaman akan membuat organisasi semakin semarak. Keberagaman dari segi usia, ras, agama, dan pengalaman akan memberikan sinergi terbaik bagi kemajuan organisasi.

Keberagaman akan membuat tiap-tiap orang mempunyai kualitas yang berbeda dan kualitas tersebut akan bisa saling mengisi satu sama lainnya. Akibatnya, organisasi akan lebih fleksibel dan adaptif dalam menghadapi berbagai benturan; karena potensi yang dimiliki organisasi yang beranekaragam.

Menciptakan pemberdayaan, tim kerja yang solid, dan menghargai keberagaman dalam organisasi akan gagal jika pemimpin dan anggota organisasi masih terjebak di dalam paradigma lama yang lebih menekankan pada pengawasan ketat, menciptakan stabilitas dan homogenitas. Masih banyak pemimpin yang sering mengarahkan bawahannya seperti mengarahkan mesinmesin, sekali jadi dan sekali perintah.

Hal tersebut sangat mustahil untuk membawa orang-orang di dalam organisasi menjadi orang-orang yang handal dan mempunyai kualitas prima, jika seorang pemimpin tidak menggunakan hati dan sikap bijaknya untuk mengarahkan dan memberdayakan mereka. Manusia mempunyai hati dan jiwa serta kebutuhan yang harus terpenuhi secara baik, sehingga penghargaan manusiawi akan menjadi syarat utama untuk hasil yang maksimal.

Pemimpin yang mempunyai perhatian tinggi, baik atas penyelesaian tugas maupun atas hubungan manusiawi, akan lebih efektif memimpin, apalagi jika ia berlaku sebagai orang yang dapat menolong bawahannya ketika berada dalam kesulitan. Pemimpin yang bijaksana, penuh cinta, dan ketulusan akan menciptakan komunikasi yang lebih terbuka, komunikasi dua arah yang akan menghasilkan pemahaman bersama yang lebih baik. Pemimpin hadir bukan untuk menanamkan beban dan kepedihan bawahannya. Akan tetapi, pemimpin hadir di tengah-tengah mereka dengan membawa kesejahteraan, rasa aman, dan penghargaan.

Pada zaman globalisasi yang melanda seluruh belahan dunia, tidak diperlukan lagi seorang pemimpin yang berkuasa penuh atas orang lain dan pemimpin yang hanya bisa mengeluarkan perintah, tetapi lebih dibutuhkan seorang pemimpin yang menjadi suri tauladan dan panutan terbaik, sebagai fasilitator, rekankerja, dan penanggung resiko yang mempunyai visi untuk menolong orang lain berkembang, belajar, berdaya guna, semakin teraktualisasi serta mampu mencapai seluruh potensi dirinya secara penuh. Tim kerja, kerjasama, pemberdayaan, inisiatif pegawai, dan komitmen untuk menghasilkan kualitas dan pelayanan prima tidak bisa melalui perintah atau undang-undang. Semuanya muncul secara alamiah dalam hati, jiwa, dan pikiran pegawai dalam organisasi.

Pegawai Negeri Sipil merupakan pilar terpenting dalam pelaksanaan tugastugas pemerintahan dan pembangunan, disamping pilar kelembagaan (organisasi) 
dan ketatalaksana (mekanisme/prosedur). Untuk memperoleh dukungan seluruh jajaran secara efektif dan efisien, perlu diterapkan teknik atau prinsip kepemimpinan yang tepat dari seorang Camat.

Sehubungan beratnya tugas dan kewajiban Camat tersebut, maka dalam menjalankan roda pemerintahan, melaksanakan pembangunan dan memberikan pelayanan kepada masyarakat, Camat harus memiliki kemampuan manajerial kepada seluruh jajarannya supaya dapat bekerjasama dalam mewujudkan tujuan instansi. Dalam kepemimpinan camat yang paling penting adalah menginterpretasikan peristiwa-peristiwa, memetakan jalannya organisasi, membangun kerja sama antar anggota organisasi untuk mencapai tujuan yang telah ditetapkan.

Berdasarkan hal tersebut maka perlu ditinjau ulang, mengkaji, menelaah, meneliti, dan membahas permasalahan tersebut secara lebih lanjut. Kemudian menyusunnya dalam bentuk penelitian dengan judul : "Fungsi Kepemimpinan dalam Meningkatkan Prestasi Kerja Pegawai Pada Kantor Camat Kedurang Kabupaten Bengkulu Selatan",

\section{B. Metode Penelitian}

Berdasarkan latar belakang, masalah dan tujuan penelitian ini maka menurut peneliti metode penelitian yang cocok digunakan yaitu kualitatif. Menurut Sugiyono (2006:8) metode penelitian kualitatif adalah metode penelitian pada kondisi obyek yang alamiah (sebagai lawannya adalah eksperimen) dimana peneliti adalah sebagai instrumen kunci, teknik pengumpulan data dilakukan secara trianggulasi (gabungan). Analisis data bersifat induktif/kualitatif, dan hasil penelitian kualitatif lebih menekankan makna dari generalisasi.

Metode ini digunakan dengan pertimbangan bahwa metode ini relevan dengan materi penulisan proposal tesis, penelitian ini dilakukan hanya bersifat deskriptif yaitu menggambarkan kenyataan dari kejadian yang diteliti sehingga memudahkan penulis untuk mendapatkan data yang objektif dalam rangka menganalisis Fungsi Kepemimpinan dalam Meningkatkan Prestasi Kerja Pegawai Pada
Kantor Camat Kedurang Kabupaten Bengkulu Selatan. Informan dalam penelitian ini yaitu Sekretaris Kecamtanan, Kasi Pelayanan Umum Kec. Kedurang, 2 Kepala Desa dan 2 Masyarakat.

\section{Hasil Penelitin}

Fungsi Kepemimpinan dalam Meningkatkan Prestasi Kerja Pegawai Pada Kantor Camat Kedurang Kabupaten Bengkulu Selatan yaitu sebagai berikut :

\section{Fungsi Instruktif}

Fungsi ini berlangsung dan bersifat komunikasi satu arah. Pemimpin sebagai pengambil keputusan berfungsi memerhatikan pelaksanaannya pada orangorang yang dipimpin. Pemimpin sebagai komunikator merupakan pihak yang menentukan apa isi perintah, bagaimana cara mengerjakan perintah, bilamana waktu memulai, melaksanakan, melaporkan hasilnya, dan dimana tempat mengerjakan perintah agar keputusan dapat diwujudkan secara efektif.

Fungsi orang yang dipimpin anggota kelompok organisasi hanyalah melaksanakan perintah. Inisiatif tentang segala sesuatu yang ada kaitannya dengan perintah itu, sepenuhnya merupakan fungsi pemimpin. Fungsi itu berarti juga keputusan yang ditetapkan pimpinan tidak akan ada artinya tanpa kemampuan mewujudkan atau menterjemahkannya menjadi instruktif perintah.

Selanjutnya perintah tidak akan ada artinya, jika tidak dilaksanakan. Oleh karena itu sejalan dengan pengertian kepemimpinan, intinya adalah kemampuan pimpinan menggerakkan orang lain agar melaksanakan perintah, yang bersumber dari keputusan yang telah ditetapkannya. Berdasarkan uraian-uraian diatas dapat disimpulkan bahwa kepemimpinan yang efektif memerlukan kemampuan menggerakkan dan memotivasi orang lain agar melaksanakan perintah. Untuk itu perintah harus jelas, baik mengenai apa yang harus dikerjakan isi perintah maupun dari segi bahasa sesuai dengan tingkat kemampuan orang menerima dan harus melaksanakannya.

Dalam kondisi tingkat kemampuan pelaksana dinilai rendah, maka harus jelas pula dalam menyampaikan cara melaksanakannya, waktu pelaksanaannya dan dimana tempat melaksanakan perintah 
tersebut. Perintah yang jelas dari segi kepemimpinan berarti juga sebagai perwujudtan proses bimbingan dan pengarahan, yang dapat meningkatkan efektivitas dan efisiensi pencapaian tujuan kelompok organisasi. Apabila terjadi kekeliruan atau kesalahan dalam pelaksanaannya, sebelum mencari sebabsebabnya pada orang yang melaksanakan perintah, sebaiknya diteliti lebih dahulu dari sudut pemberian perintah tersebut. Kekeliruan atau kesalahan dalam pelaksanaannya, sebelum mencari sebabsebabnya pada orang yang melaksanakan perintah, sebaliknya diteliti lebih dahulu dari sudut pemberian perintah tersebut. Kekeliruan atau kesalahan itu mungkin saja terjadi karena ketidakjelasan dalam menyampaikan apa, bagaimana, bilamana dan dimana perintah harus dilaksanakan.

Proses implementasi yang memang tidak tercapai, namun penyampaian atau komunikasi yang disampaikan dari pimpinan kepada pegawai sudah jelas dan tepat sasaran. Pada Kecamatan Kedurang diketahui bahwa pada bagian pelayanan umum masih kurang maksimal yang diberikan pegawai kepada masyarakat, seperti pelayanan pembuatan eKTP yang dinilai masih lamban dan berteletele pengurusannya. Banyak masyarakat yang mengeluhkan ini, dikarenakan memang ada hambatan pada mekanisme yang tidak memadai.

Bapak Camat sudah memberikan instruksi yang baik kepada pegawai, namun pegawai tidak dapat mengimplementasikan perintah tersebut dikarenakan memang motivasi kerja pegawai dan kurangnya pemahaman terhadap komunikasi yang baik terhadap pelayanan masyarakat

\section{Fungsi Konsultatif}

Fungsi ini berlangsung dan bersifat komunikasi dua arah, meskipun pelaksanaannya sangat tergantung pada pihak pemimpin. Pada tahap pertama dalam usaha menetapkan keputusan, pemimpin kerap kali memerlukan bahan pertimbangan. Konsultasi itu dapat dilakukannya secara terbatas hanya dengan orang-orang tertentu saja, yang dinilainya mempunyai berbagai bahan informasi yang diperlukannya dalam menetapkan keputusan.

Di samping itu mungkin pula konsultasi itu dilakukannya untuk mendengarkan pendapat dan saran, apabila suatu keputusan yang direncanakannya ditetapkan. Selanjutnya konsultasi dapat pula dapat dilakukan secara meluas melalui pertemuan dengan sebagian besar atau semua anggota kelompok organisasinya. Konsultasi seperti itu dilakukan apabila keputusan yang akan ditetapkan sifatnya sangat prinsipil penting, baik bagi kelompok organisasi maupun sebagian besar seluruh anggotanya.

Tahap berikutnya konsultasi dari pimpinan pada orang-orang yang dipimpin dapat dilakukan setelah keputusan ditetapkan dan sedang dalam pelaksanaan. Konsultasi itu dimaksudkan untuk memperoleh masukan berupa umpan balik (feed back), yang dapat dipergunakan untuk memperbaiki dan menyempurnakan keputusan-keputusan yang telah ditetapkan dan dilaksanakan.

Konsultasi dapat dilakukan secara terbatas atau diperluas, sebagaimana telah diutarakan diatas. Konsultasi dapat dilakukan melalui arus sebaliknya, yakni dari orang-orang yang dipimpin kepada pemimpin yang menetapkan keputusan dan memerintahkan pelaksanaannya. Konsultasi dapat dilakukan secara perseorangan atau kelompok dengan jumlah anggota yang terbatas.

Konsultasi dapat berupa memberi kesempatan menyampaikan saran dan pendapat sebelum atau sesudah keputusan ditetapkan. Konsultasi sebelum keputusan ditetapkan dapat terjadi apabila pemimpin bersikap terbuka, sehingga meskipun anggota hanya mendengar suatu issu atau sekedar menduga akan ditetapkan suatu keputusan, selalu dibenarkan untuk membicarakan dengan pemimpin. Konsultasi sesudah keputusan ditetapkan dapat dilakukan untuk memberikan kesempatan bertanya, jika setelah diturunkan berupa perintah ternyata tidak jelas.

Di samping itu seperti dikatakan diatas dapat pula digunakan untuk menyampaikan pendapat dan saran, dalam rangka perbaikan atau penyempurnaan keputusan atau pelaksanaannya. Dengan menjalankan fungsi konsultatif dapat diharapkan keputusan-keputusan pimpinan, akan mendapat dukungan dan lebih mudah menginstruksikannya, sehingga kepemimpinan berlangsung efektif. Fungsi konsultatif ini mengharuskan kepemimpinan 
MIMBAR

JURNAL PENELITIAN SOSIAL DAN POLITIK

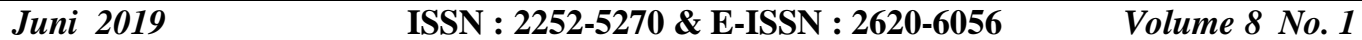

belajar menjadi pendengar yang baik, yang biasanya tidak mudah melaksanakannya, mengingat pemimpin lebih banyak menjalankan peranan sebagai pihak yang didengarkan. Camat Kedurang sebagai pimpinan dari bawahannya juga sebaiknya meyakinkan diri, memiliki gagasan, aspirasi, saran dan pendapat yang konstruktif bagi pengembangan kepemimpinannya.

Untuk itu pemimpin harus menyakinkan dirinya bahwa dari siapa pun juga selalu mungkin diperoleh gagasan, aspirasi, saran dan pendapat yang konstruktif bagi pengembangan kepemimpinannya. Memang fungsi ini dibutuhkan karena memang mengingat konsultasi sangat membantu pegawai dalam memecahkan masalah yang dihadapinya serta dapat melakukan konsultasi dengan pimpinannya. Di Kecamatan Kedurang sendiri, hal ini sudah dijalankan oleh pimpinan, dan implementasi dari fungsi ini adalah pegawai menjadi dapat mengintrospeksi dirinya guna mengevaluasi semua yang sudah dikerjakan, serta dapat menciptakan rasa percaya diri atas kemampuan yang dimiliki

\section{Fungsi Partisipasi}

Kepemimpinan akan efektif jika disesuaikan dengan tingkat kematangan pegawai. Kepemimpinan partisipatif didefinisikan seorang pemimpin mengikutsertakan anak buah bersama-sama berperan didalam proses pengambilan keputusan. Model kepemimpinan seperti ini diterapkan apabila tingkat kematangan anak buah berada pada taraf kematangan moderat sampai tinggi. Mereka mempunyai kemampuan, tetapi kurang memiliki kemauan kerja dan kepercayaan diri.

Menurut Burhanuddin dalam bukunya analisis administrasi manajemen dan kepemimpinan pendidikan, mendefinisikan model kepemimpinan partisipatif sama pengertiannya dengan kepemimpinan demokratis, yaitu seorang pemimpin mengadakan konsultasi dengan para bawahannya mengenai tindakan-tindakan dan keputusan-keputusan yang diusulkan atau dikehendaki oleh pimpinan, serta berusaha memberikan dorongan untuk turut serta aktif melaksanakan semua keputusan dan kegiatan-kegiatan yang telah ditetapkan.

Selain itu telah dipahami juga bahwa kepemimpinan dengan menggunakan gaya atau model partisipatif yaitu seorang pemimpin dan pengikut atau bawahannya saling tukar menukar ide dalam pemecahan masalah dan pembuatan keputusan. Dalam hal ini komunikasi dua arah ditingkatkan dan peranan pemimpin adalah secara aktif mendengar. Tanggung jawab pemecahan masalah dan pembuatan keputusan sebagian besar berada pada pihak pengikut atau bawahan. Hal ini sudah sewajarnya karena pengikut atau bawahan memiliki kemampuan untuk melaksanakan tugas.

Teori kepemimpinan empat faktor menurut Lipham dan Hankom, mencakup empat dimensi kepemimpinan, yaitu kepemimpinan partisipatif, kepemimpinan struktural, kepemimpinan suportif dan kepemimpianan fasilitatif. Jadi, kepemimpinan partisipatif termasuk teori kepemimpinan empat faktor tersebut. Model kepemimpinan partisipatif merupakan model yang menyediakan peluang seluas dan sebaik mungkin kepada bawahan untuk berpartisipasi dalam setiap kegiatan yang menguntungkan kelompok dan individu yang dipimpinnya. Wewenang dari seorang pemimpin yang diberikan kepada bawahan terukur dan sebatas wewenang yang diberikan organisasi dan kedudukannya. Hubungan yang terjalin dan bersifat kekeluargaan antara atasan dengan bawahan dapat dihindari sehingga mereka melaksanakan hubungan kerja sesuai dengan aturan organisasi fungsi deligasi.

Sehingga pada Kantor Camat Kedurang dalam proses pengambilan keputusan dan penentuan target pemimpin selalu melibatkan bawahannya, guna membangun dan meningkatkan partisipasi pegawainya. Dalam sistem ini pola komunikasi yang dilakukan oleh Camat Kedurang adalah komunikasi dua arah dengan memberikan kebebasan kepada bawahan untuk menyampaikan seluruh ide ataupun permasalahan yang berhubungan dengan pelaksanaan pekerjaan.

Pegawai kantor Camat kedurang juga selalu terlibat dalam kegiatan-kegiatan kantor maupun acara yang melibatkan pemerintahan kantor camat kedurang. Hal ini menjadi penting karena partisipasi dapat meningkatkan prestasi kerja pegawai kantor camat kedurang, baik dari segi aktualisasi diri dan pemberdayaan bagi mereka. 
MIMBAR

JURNAL PENELITIAN SOSIAL DAN POLITIK

\section{Fungsi Deligasi}

Menurut (Rokar: 2010) dalam hal delegasi ini pemimpin biasanya memberikan suatu tanggung jawab kepada orang lain dalam hal ini bawahannya untuk melaksanakan kegiatan yang biasanya dikerjakan oleh pemimpin dan pemimpin bertanggung jawab terhadap tindakan tindakan yang dilakukan oleh bawahan yang ia beri delegasi.

Dalam menjalankan delegasi ada hal yang perlu diperhatikan sebab sebuah delegasi mempunyai resiko dan rasa takut pemimpin karena adanya jarak antara kita dan orang yang kita serahi delegasi. Ada unsur-unsur yang terkait dalam delegasi yang perlu diperhatikan :

1. Apa yang didelegasikan

2. Komunikasi terbuka antara orang yang menyerahkan delegasi dan orang yang menerima delegasi

3. Kejelasan isi delegasi

4. Harapan yang diletakan pada orang yang dietakkan delegasi

5. Kekuasaan yang diserahkan

6. Pengawasan yang wajar

7. Orang yang diserahi delegasi

Hal-hal yang penting yang perlu diperhatikan oleh pemimpin dalam memberikan delegasi pada bawahan, adapun hal - hal yang dapat membantu, antara lain :

1. Perhatikanlah orang yang hendak kita beri delegasi, mengapa orang itu kita minta dan apa tepatnya hal yang akan kita minta kepadanya

2. Jelaskan permintaan itu dengan tenang dan dalam situasi santai, orang yang akan kita beri delegasi kita beri latar belakang tugas dan hal-hal yang mungkinkan tersangkut dalam tugas itu

3. Sampaikanlah harapan kita dan jelaskan kekuasaan yang kita berikan kepadanya. Dan mintalah dia mulai bekerja melaksanakan tugas yang kita serahkan kepadanya

4. Jika dia sanggup, beritahukanlah bagaimana kita dapat membantunya demi suksesnya pelaksanaan tugas itu

5. Hendaklah kita setia pada kesepakatan yang telah dibuat, apabila dia ingin perubahan bicarakanlah pada dia dan utarakan alasan alasannya. Jika delegasi telah selesai ucapkanlah terima kasih kepadanya, bahkan dimuka umum jika dirasa tepat.

Pendelegasian yang dilaksanakan dan ditentukan oleh camat keduarang kepada pegawainya seringkali di wewenangkan dengan sekretaris camat yang memang paling sering menerima delegasi ini, terutama untuk menghadiri undangan musyawarah desa atau musrenbang di desa, ataupun hanya sekedar memimpin rapat ketika camat berhalangan.

Namun tidak semua pegawai diberikan delegasi, karena memang mengingat kepentingan dari suatu tugas delegasi tersebut, dan kenyataan dilapangan juga menunjukkan masih banyak pegawai yang tidak mencukupi dalam hal SDM nya untuk diberikan delegasi ini.

\section{Kesimpulan dan Saran}

\section{Kesimpulan}

Berdasarkan hasil penelitian dan analisis yang dilakukan peneliti diperoleh kesimpulan bahwa Fungsi Kepemimpinan Dalam Meningkatkan Prestasi Kerja Pegawai Kantor Camat Kedurang Kabupaten Bengkulu Selatan dapat dikategorikan optimal. Hal ini dapat dilihat dari beberapa indikator sebagai berikut :

1. Fungsi Instruktif, belum terkategori optimal, namun kenyataannya implementasi dari prestasi kerja pegawai belum mengalami peningkatan.

2. Fungsi Konsultatif, sudah memperlihatkan hasil yang maksimal, dikarenakan pimpinan mampu berkonsultasi dengan pegawainya, outputnya adalah pegawai menjadi dapat memecahkan masalah, lebih termotivasi dan percaya diri dalam kinerjanya.

3. Fungsi Partisipasi, fungsi ini sudah memperlihatkan hasil yang maksimal dalam meningkatkan prestasi kerja pegawai dalam aspek kerjasama dan kesadaran pegawai untuk saling bekerjasama tim juga.

4. Fungsi Delegasi, walaupun masih ada sebagian kecil pegawai yang masih kurang maksimal SDMnya, tetapi fungsi ini sudah terlaksana dan optimal, dikarenakan 
pendelegasian ini sudah tepat di delegasikan oleh pimpinan

\section{Saran}

Berdasarkan kesimpulan yang sudah dijelaskan diatas, maka dapat diberikan saran atau masukan sebagai berikut :

1. Indikator fungsi instruktif, sebaiknya pemimpin lebih tegas lagi dalam mengintruksikan perintah dan peraturan yang ada sesuai dengan SOP, agar pegawai dapat lebih terarah dan tidak melenceng dari tugas dan fungsinya.

2. Indikator fungsi konsultatif, ada baiknya pemimpin terus melakukan follow up terhadap pegawai agar pegawai aktif dan mau berkonsultasi atas permasalahan yang sedang dikerjakannya.

3. Indikator fungsi partisipasi, pegawai sebaiknya tidak hanya berpartisipasi dalam kegiatan kantor saja, tetapi kegiatan luar kantor juga dilaksanakan.

4. Indikator fungsi delegasi, sebaiknya juga memberikan kesempatan bagi kasubag atau pegawai lainnya, tidak hanya terarah kepada Sekretaris Camat saja dalam melaksanakan wewenang dari pimpinan.

\section{DAFTAR PUSTAKA}

Arikunto, Suharsimi. 1996, Prosedur penelitian, Suatu Pendekatan Praktis, Jakarta, Bina Aksara.

George R. Terry, 1960. Principle of Management, 3 rd edt. Homewood, Illinois, Record D. Irwin, Inc

Hasibuan, Malayu S.P. 2008. Manajemen Sumber Daya Manusia. Jakarta :Penerbit Bunii Aksara.

Kamus Besar Bahasa Indonesia, 2007, Edisi Ketiga, Balai Pustaka, Jakarta.

Kartono, Kartini. 2005. Pemimpin dan Kepemimpinan. PT. Raja Grafindo Persada. Jakarta.

Moleong, Lexy, J., 2000, Metode Penelitian Kualitalf, PT. Remaja Rosdakarya, Bandung.

Nawawi, Hadari \& Hadari, Martini, M. 2004. Kepemimpinan yang Efektf,
Gajah Mada University Press: Yogyakarta.

Siagian, Sondang. P. 2010.Teori dan Praktek Kepemimpinan. PT. Rineka Cipta Jakarta.

Sugiyono, 2008. Memahami Penelitian Kualitatf, Bandung: CV. ALFABETA Thoha, Mifta. 1990, Kepemimpinan Dalam Manajemen. Jakarta, Rajawali

Winardi. 2000. Kepemimpinan dan manajemen. PT Rineka Cipta. Jakarta 